\title{
ОБРЕД - ОСОБЕНИ ВИД НАРОДНЕ ДРАМЕ У СРБА, ОБРЕД - ПРИПРЕМА РЕЦЕПЦИЈЕ КОМАДА С ПЕВАЮЕМ У СРБА
}

Довођење у блиску узрочно-последичну везу народних обреда везаних за обележавање смене годишњих доба, или, пак, за обележавање значајних догађања у пољопривредном или сточарском народном календару једнако је резултат поузданих научних истраживања, али и одраз помодних научних и псеудонаучних струјања.

У историјама позоришта, односно театра, у историјским прегледима развоја драме, у стручној приручној литератури - порекло класичне (западноевропске) драме и позоришта (тзв. Urthetar) изводи се из свечаности које су у Старој Грчкој приређиване у част бога Диониса ${ }^{1}$. У с р п ској те ат ролог и ј и веома је присутно домишљање Мираша Кићовића, иначе свакојако колебљиво и смућено, како позориште и драма у Срба не исходе, једнако као ни код Руса, из религиозног култа, „као код других народа, рецимо код Грка и Француза"2. У првом делу студије Кићовић заступа став како драма у Срба нема никакве везе са обредима,

1 Р. Јовановић, Позориште и драма. Библиотека „Човек и реч”, Београд, „Вук Караџић”, 1984, под речју позориште. Из дионисијских свечаности „на којима се певао дитирамб (химна у част бога Диониса), који ће добити назив трагедија, откад га прати жртвовање јарца; кад се хор поделио на полухорове с корифејима на челу, дошло је до дијалога; на то је једна личност почела одговарати Дионисове речи, симболишући присуство божанства. Тренутак кад је једна личност почела одговарати у првом лицу на певање и дијалоге полухорова и корифеја сматра се почетком позоришта. Убрзо су почели песмом славити и дозивати друга божанства, па и поједине јунаке, те су свечаности сасвим измениле карактер; дошло је до пројекције ликова које призива и слави хор, настаје представа".

2 М. Кићовић, Старо позориште код Срба, Зборник радова Института за проучавање књижевности, књига 1, Београд, Српска академија наука, 1951, 9. 
попут оног дионисијског, а да су српској средњовековној драми потпуно страни драмски облици, као што су мистерије, моралитети и дијалози. Њих је православна црква, насупрот римокатоличкој, избегавала ${ }^{3}$. Међутим, у даљем излагању Кићовић указује на постојање религиозног позоришта у Византији (од V до XV века) и допушта вероватноћу да је нешто слично могло да постоји и у српској православној цркви будући да су Срби од Византије са хришћанством примили и „архитектонски тип цркве, догматске изразе, обред”. Сводећи досадашње расправе, размишљања и премишљања о настанку позоришта у Срба, Рашко Јовановић је у лексикону Позориште и драма указао на позоришни карактер „народних игара под маскама нехришћанског порекла” (коледа, лазарице, краљице). Том приликом је истакао и да „иако у средњевековној српској књижевности нема драмских текстова, могућно је закључити како је било позоришних манифестација у виду пучког театра, на улицама, трговима или отвореним пољима"4. У стручној литератури у нас се често шпекулисало називима извођача позоришних представа. Тврђено је, наиме, да је реч глумаи, којом се данас именује извођач позоришне представе била у нас у употреби већ од XIII века „у значењу народни играч, забављач и изједначује се с шпилманом"5. Чини се да је назив глумаи, данашњу семантику добио тек временом, а да је у почетку означавао пре свега свирача који свирком забавља присутне. Томе у прилог сведоче и некоји приморски писци шеснаестог и седамнаестог века. Мавро Ветрановић, на пример, позива глумце: „А сад глумци, вас молимо, справте дипли да се свири”. Слично бележи и Гундулић: „Тебе су позвали за глумца пастири - ки не имаш свирали, ни ко се знаш свири". Временом тим називом се подразумева и шала, па и шаљиво-забављачки говор. У Петра Зоранића срећемо, примерице, израз „глумно бесидити”. Свакојако јесте значајно што је назив глумац подразумевао личност која на различите начине (свирком, речју, гестом, мимиком) забавља присутне и тиме обезбеђује властиту егзистенцију.

Истраживање народног позоришта и народне драме подразумева у полазишту привремено или трајно опредељивање за некоји од могућих углова посматрања. Дакако, неопходно је у самоме почетку разлучити

${ }^{3}$ Исто, 9 - „Насупрот римокатоличкој цркви, која је увелико неговала драму она је драмске елементе избегавала".

${ }^{4}$ Р. Јовановић, Нав. дело, под синтагмом: позориште у Југославији.

${ }^{5}$ Нав. дело, под речју глумаи. В. Д. Драгојловић, Вести о позоришту у средновековној јужнословенској кюижевности. [У књизи:] Фолклорни театар у балканским и подунавским земљама. Зборник радова, Београд, Балканолошки институт Српске академије наука и уметности, 1984, 75-79. 
драмске елементе у усменом народном стваралаштву од онога што би имали право да назовемо народном драмом и народним позориштем. Несумњиво је, на пример, да гусларево извођење какве јуначке епске песме можемо упоредити са монодрамом. Гуслар, посебно обучен за ту прилику, ставља себе на уочљиво место и започиње властиту представу. Окружује га публика која непосредно по почетку „представе” слободно одлучује да ли ће „представу” одслушати и одгледати до краја или ће је незаинтересована, можда и незадовољна - напустити. Од певачеве висине и боје гласа, од његовога свеукупног држања, од вештине стварања и наглашавања драмских пауза, од способности да држи, да задржава и да, коначно, господари пажњом окупљених - зависи и коначан успех „монодраме”. Међутим, мада поменута сличност постоји, иако се она може и показивати и доказивати, гуслање и певање епских песама суштински није драма. Три главна догађања у човековом животном циклусу: рођене, свадба и смрт - такође су препуни драмских елемената. Постоје и одређени типски ликови, типске улоге као, примерице, у комедији дел' арте. Приликом обреда рођења тачно се зна шта теба да чини породиља, шта супруг, шта комшије, родбина, пријатељи, а шта бабица. Једнако се у свадбеном обреду знају улоге кума, старог свата, барјактара, девера, а да не говоримо о чаушу 6 . Догађање смрти такође подразумева поштовање исконског синопсиса поступака - који се у основи и редоследу мора испоштовати, али где поједини сегменти могу да трају краће или дуже зависно од емоционалне узбуђености и понесености учесника. Улога нарикача, тужилица неспорно је драмска. Обележавање животног циклуса човековог обилује драмским елементима и „типским улогама”. Међутим, то није ни народно позориште, нити народна драма у правом значењу тих појмова. У свим кључним животним догађањима учесници збивања (рођеньа, свадбе, смрти) посебно се припремају и удешавају за чин који предстоји, односно за чин који је у току. Облаче се посебно, често се чешљају посебно, али они се не прерушавају, не менају свесно природу и суштину свога бића. Основни критеријум за препознавање народног позоришта, народне драме морао би да подразумева уочавање постојања свесног физичког и менталног прерушавања учесника. Учесници се, дакле, маскирају, а током познијег „извођења”, изговарају кратке или дуже текстове у духу одлика које подразумева биће чију маску носе. Други помињани чинидбени елементи народног позоришта, односно драме,

${ }^{6}$ Д. Николић, Чаущ као глумаи, и редител. [У књизи:] Фолклорни театар у балканским и подунавским земљама, 181-189; Бреда Влаховић: Народно глумовате у свадбеним обичајима Русина у Војводини, исто, 171-178. 
попут, примерице, постојања акције, или естетске функције „као уметничко оплемењивање акције” - на особен начин се суштински подразумевају ${ }^{7}$.

Обреди животног циклуса и годишњег календара подразумевају постојање прецизног синопсиса, као и одсуства разрађеног, издетаљисаног сценарија. Постоје задате, познате теме и типске улоге. Све остало подложно је мањој или већој импровизацији. Годишњи календар обичајних народних поступања и радњи јесте заправо особени, симболични, некад имитативно-магијски, некад алегоријски вид узајамности човека и природе. Посредник између човека-јединке, који подразумева живот у тренутку, у пролазности, и природе која собом означава вечиту променљивост и непролазност јесте предак (односно преци) који је чином смрти постао непролазан, нераскидиви део природе „до даљег”. Сви обреди годишњег календара, од тзв. коледарских опхода који се догађају између светога Игњатија Богоносца и Божића, преко ранилачких, лазаричких, ђурђевданских, јеремијских до краљичких опхода и ивањданских и петровданских кресова јесу непрекидна, наглашена узајамност овога и онога света, узајамн ост којој је циљ да у тренутку допринесе пролазним, временски ограниченим плодовима земље. У таквом синопсису, уистину се може унапред одредити само основно: опход села, обилажење свакога домаћинства, понављање магичних доброжелећих и злогонећих речи. Импровизацији учесника обреда препуштено је реаговање на тренутно понашање саме природе, појединих домаћина, њихове чељади или, пак, успутних сусретача и намерника.

Покладе и различни коледарски опходи села позоришном природом и драмским елементима привлачили су позорност проучавалаца фолклорног театра ${ }^{8}$. Битну одлику народног глумовања пропуштали су, чини се, да уоче. Наиме, пресудна одлика народнога, односно фолклорнога позоришта и народне, односно фолклорне драме, јесте у чињеници да у народноме позоришту, у народној драми, нема гледалаца, нема посматрача. У „позоришној представи”, у „драми” учествују сви. Разликују

7 Д. Антонијевић, Опште теоријске претпоставке о фолклорном театру. [У књизи:] Фолклорни театар у балканским и подунавским землама, 3.

8 Л. Костић, Народно глумоваюе. [У књизи:] Народна кюижевност. Српска књижевност у књижевној критици. Приредио Владан Недић: Београд, Нолит, 1972², 539-551; Д. Јанковић, Драмски елементи у намим народним српским играма и народна српска игра као драмски елеменат народних обичаја, Гласник Етнографског музеја, књига XV, Београд, 1940, 75-93; М. Прошић-Дворнић, Покладни ритуал. [У књизи:] Фолклорни театар у балканским и подунавским земљама, 143-156. 
се само по томе што су једни прерушени, а други само нису свакидашње обучени. Први су се изменили битно - ликом, понашањем, речју; други - делимично, али су остали препознатљиви. И једни и други, пак, јесу учесници драме. Нема трага од позније, класичне позоришне поделе на: глумце и гледаоце. Фолклорни театар и фолклорна драма јесу особено догађање. У томе догађању може се учествовати активније или статичније, али посматрати га са стране - није могуће.

Истраживачи фолклорног театра и тзв. народне драме знатни део времена и простора (попут Лазе Костића или Данице Јанковић) посветили су размишљањима о драмским елементима у орским играма, као и у некојим дечјим играма. Ова испитивања су, природно, западала у својеврсни ћор-сокак, јер није увек био анализи доступан и јасан митски архетип који је био окамењен у односној орској или тзв. дечијој игри (На пример: Јежо-Јежо, Изникнала коноплька или Змија. Прва је пореклом мушка игра и играла се на други дан Ускрса, у затвореном колу, на Косову, временом је постала дечија игра; друга је женска игра која је се такође изводила на други дан Ускрса, временом је постала дечија игра) ${ }^{9}$.

Интересантно је да проучаваоце народног позоришта и народне драме није привукло питање могућег утицаја некојих популарних народних обреда, односно обичаја на поспешивање рецепције извесних типова драме у ширим круговима гледалаца. Пада, наиме, у очи да су на балканским просторима тзв. комади с певањем уживали увек лепу популарност и били вазда у жижи интересовања балканске позоришне публике. Мислим, да се та наклоност може понајједноставније објаснити утицајем народних обреда годишњег календара. Природом, полазишном мешавином песме, речи и крета, народни обреди су изградили уверење код мање активних, непрерушених учесника обреда, код особених посматрача - како је најприроднији облик драме онај који подразумева смешу маски, певања, говора и кретања. Процесом десакрализације обреда, тзв. песма престајала је да буде свети, обредни текст везан за временски тренутак. Такав текст, таква песма могли су се, након десакрализације, казивати или певати у било које време, на било којем месту, у свакојим приликама без икаквих сакралних последица. Свест о обреду у коме су маскиране личности играле, певале, говориле и кретале се створила је неопходну повољну климу за прихватање комада са певањем, а сам процес десакрализације обреда помогао је да се у позоришту човек из народа понаша и осећа само као - гледалац.

9 Видети: Д. Јанковић, Нав. дело, 79, 81-82; Љ. и Д. Јанковић, Народне игре, II, Београд, 1937, 51; Љ. и Д. Јанковић, Народне игре, I, Београд, 1934, 28-30. 
Nenad Ljubinković

\section{RITUAL - SPECIFIC FORM OF FOLK DRAMA THAT PREPARED RECEPTION OF SERBIAN MUSIC PLAY}

\section{Summary}

The annual calendar connected rituals were a sort of dramatic performances with specific texts, songs, masks and movements. In a desacralisation process, a ritual text lost its sacred nature connected to a strict calendar moment. It became a form which could be told or sung in every time, on every place and in every occasion. It was the memory of a rite, with its masks, songs and dances, that made possible a music play to be accepted by the people. In a ritual performance participants were both spectators and actors. Later, in a theatre performance spectators and actors were definitely separated. 